\title{
STUDI POLA PERGERAKAN PENUMPANG DI TITIK TRANSIT (STUDI KASUS : STASIUN MRT BLOK M DAN TERMINAL BUS BLOK M, KEBAYORAN BARU, JAKARTA SELATAN)
}

Felicia Sugita ${ }^{1)}$, Suryono Herlambang ${ }^{2)}$, Parino Rahardjo ${ }^{3)}$

1)Program Studi S1 PWK, Fakultas Teknik, Universitas Tarumanagara, feliciasugita@gmail.com

2) Program Studi S1 PWK, Fakultas Teknik, Universitas Tarumanagara, suryonoh@ft.untar.ac.id

3) Program Studi S1 PWK, Fakultas Teknik, Universitas Tarumanagara, parinor@ft.untar.ac.id

\begin{abstract}
Abstrak
Kawasan Blok M merupakan kawasan pusat komersial Kecamatan Kebayoran Baru yang memiliki aksesibilitas dan kedudukan yang cukup strategis terhadap kota Jakarta dan menjadi salah satu kawasan yang dilintasi berbagai moda angkutan umum yang tidak hanya melayani penduduk tingkat kecamatan, tetapi juga melayani penduduk kota Jakarta. Keberadaan Terminal Bus Blok M, Transjakarta, kemudian sekarang ditambah dengan adanya jaringan Jakarta Mass Rapid Transit (MRT) membuat Blok M menjadi kawasan transit intermoda dan menjadikan Blok M sebagai tujuan perkantoran, wisata hiburan dan wisata belanja. Namun pada kenyataannya kawasan TOD yang direncanakan seharusnya dapat menghubungkan antarmoda transportasi belum sepenuhnya terlaksana dengan baik di Kawasan Blok M. Studi ini dilakukan untuk mengetahui mobilitas penumpang, kondisi jalur pejalan kaki, dan aktivitas pendukung yang ada di kawasan Blok M. Kemudian studi dilakukan dengan metode analisis kualitatif dan kuantitatif. Pendekatan kualitatif untuk melihat profil dari penumpang di titik transit, mobilitas penumpang, kondisi jalur pejalan kaki, dan aktivitas pendukung di titik transit. Kemudian, pendekatan kuantitatif digunakan untuk melihat simulasi dari proyeksi jumlah penumpang berdasarkan RDTR 2030 dan PRK 2020. Berdasarkan studi yang telah dilakukan, bahwa mobilitas yang ada di kawasan Blok $\mathrm{M}$ dapat dikatakan belum maksimal, hanya $30 \%$ penumpang yang melakukan perpindahan moda transportasi. Beberapa kriteria yang belum terpenuhi untuk kondisi jalur pejalan kaki yang ada di kawasan Blok $\mathrm{M}$, terutama terkait masih adanya konflik yang terjadi antara pejalan kaki dengan pengguna kendaraan pribadi. Dan aktivitas pendukung yang paling mendominasi kawasan Blok $\mathrm{M}$ adalah pusat perbelanjaan dan pertokoan.
\end{abstract}

Kata kunci: Blok M; Mobilitas; Pejalan Kaki; Stasiun MRT; Terminal Bus

\begin{abstract}
Blok $M$ is the commercial centre area of Kebayoran Baru District, which has accessibility and a strategic position to the city of Jakarta. It also an area that is crossed by variety of public transportation and it not only serves residents at the sub-district level, but also residents of Jakarta. The existence of Terminal Bus Blok M and now there is MRT Station, it makes Blok M an intermodal transit area and also a destination for office, entertainment, and shopping. However, Transit Oriented Development area that should be able to connect between transportation modes, it has not been fully implemented well in Blok $M$. This study is conducted to determine about pedestrian mobility, pedestrian way conditions, and supporting activities in Blok $M$. The study is conducted using quantitative and qualitative analysis methods. A qualitative analysis to look at the profile of the pedestrian at the transit area, mobility of pedestrian, pedestrian way conditions, and supporting activities at the transit area. The quantitative analysis used to view the simulation of the estimated number of passengers based on the RDTR 2030 and PRK 2020. Based on studies conducted, the mobility in Blok $M$ area is not maximized, only $30 \%$ of passengers change transportation modes. There are several criteria that have not been met for the condition of the pedestrian way in the Blok $M$, especially related to the conflict that occurs between pedestrians and private vehicle users. The supporting activity in this area are dominated by shopping centres and shops.
\end{abstract}




\section{PENDAHULUAN}

\section{Latar Belakang}

Sebagai kota metropolis Jakarta harus mampu dalam menyelenggarakan pembangunan guna meningkatkan kesejahteraan warganya. Dalam menciptakan tata ruang kota yang baik juga perlu didukung dengan adanya perencanaan sistem transportasi. Dalam perkotaan perencanaan sistem transportasi ini dibuat berkelanjutan yang secara khusus diartikan sebagai sistem transportasi yang tidak menimbulkan dampak yang dapat membahayakan bagi kesehatan masyarakat atau lingkungan serta dapat memenuhi kebutuhan mobilitas yang ada dengan konsisten (OECD, 2002). Dalam sistem transportasi berkelanjutan ini perencanaan penataan ruang perkotaan perlu dikembangkan dengan konsep Transit Oriented Development (TOD).

Kawasan Blok $\mathrm{M}$ berada di Kecamatan Kebayoran Baru dimana Blok $\mathrm{M}$ juga menjadi kawasan pusat komersial yang ada di Kebayoran Baru. Kawasan Blok M memiliki aksesibilitas yang tinggi dan kedudukan yang cukup strategis terhadap kota Jakarta dan menjadi salah satu kawasan yang dilintasi berbagai moda angkutan umum yang tidak hanya melayani penduduk tingkat kecamatan, tetapi juga melayani penduduk kota Jakarta. Keberadaan Terminal Bus Blok M, Transjakarta, kemudian sekarang ditambah dengan adanya jaringan Jakarta Mass Rapid Transit (MRT) membuat Blok M menjadi kawasan transit intermoda dan menjadikan Blok $M$ sebagai salah satu tujuan perkantoran, wisata hiburan dan wisata belanja.

Kawasan TOD Blok $\mathrm{M}$ ini diharapkan akan menumbuhkan kawasan bisnis baru dan dapat menggerakkan serta meningkatkan perekonomian. Namun pada kenyataannya kawasan TOD yang direncanakan seharusnya dapat menghubungkan antarmoda transportasi belum sepenuhnya terlaksana dengan baik di Kawasan Blok M. Stasiun MRT Blok M dengan Terminal Blok M juga masih dalam radius $400 \mathrm{~m}$ sehingga sangat mudah dicapai bagi pejalan kaki (walkable), bila integrasi antarmoda transportasi tersebut direncanakan dengan matang maka Kawasan Blok $\mathrm{M}$ akan dapat meningkatkan mobilitas penumpang di titik transit. Tata guna lahan yang ada pada Kawasan Blok M ini sangat bervariasi. Seharusnya potensi yang ada di Kawasan Blok $\mathrm{M}$ ini didukung dengan adanya jalur pedestrian yang berfungsi sebagai penghubung kedua titik transit, tempat wisata, perkantoran, dan fasilitas umum lainnya sehingga dapat memaksimalkan aktivitas yang ada di kawasan tersebut.

Berdasarkan permasalahan yang ada, dapat dilihat bahwa dalam memenuhi kebutuhan dan karakteristik pejalan kaki serta faktor-faktor yang mempengaruhi perjalanan dari pejalan kaki sangat penting dalam suatu perencanaan dan perancangan fasilitas pejalan kaki. Sehingga dalam rangka meningkatkan kualitas kehidupan yang lebih baik seperti meningkatnya walkability, konektivitas, kualitas udara, dan mendorong pertumbuhan ekonomi di Kawasan Blok M, pemahaman mengenai masalah dan hubungan antara objek yang ada di dalam lingkungan tersebut merupakan hal yang utama termasuk pejalan kaki sebagai manusia dengan perilakunya, perancangan fasilitas dan layanan publik, serta pengaturan objek fisik lainnya. Maka melihat hal ini, penulis tertarik untuk melakukan penelitian terkait studi pola pergerakan penumpang di titik transit dengan studi kasus Stasiun MRT Blok $M$ dan Terminal Bus Blok $M$ diharapkan dapat mengerti bagaimana ruang kota yang diperuntukkan serta dimanfaatkan oleh pejalan kaki.

\section{Rumusan Permasalahan}

Kawasan TOD merupakan kawasan yang dibuat untuk menghubungkan antarmoda transportasi sehingga dapat mengurangi aktivitas penggunaan kendaraan pribadi, namun pada kenyataannya kawasan TOD yang ada di Blok $\mathrm{M}$ belum bisa mengintegrasikan antarmoda transportasi. Dimana setelah adanya Stasiun MRT Blok M seharusnya dapat langsung terintegrasi dengan Terminal Bus Blok M. Tata guna lahan yang ada di Kawasan Blok $M$ juga bervariasi sehingga memiliki potensi dalam mengembangkan kawasan tersebut namun belum didukung dengan jalur pedestrian yang dapat mengintegrasikan tata guna lahan dengan moda transportasi yang ada. 


\section{Tujuan}

Tujuan dari penelitian ini adalah yang pertama untuk mengetahui mobilitas penumpang yang ada di Stasiun MRT Blok M dan Terminal Bus Blok M. Selanjutnya yang kedua adalah mengetahui kondisi jalur pergerakan pejalan kaki yang berada di titik transit. Dan yang terakhir adalah mengetahui aktivitas pendukung yang ada di sekitar kawasan titik transit.

\section{KAJIAN LITERATUR}

\section{Mobility Hub}

Sebuah mobility hub adalah suatu tempat di kawasan perkotaan yang merupakan konsentrasi intensif yang menarik pekerjaan, kehidupan, belanja dan kesenangan di sekitar persimpangan transit (Metrolinx, 2008). Mobility hub membantu dalam menginformasikan tujuan mobility hub yang dapat memenuhi kebutuhan transportasi inti dan membantu memandu perkembangan mereka. Berikut adalah tujuan dari mobility hub (Aono, 2019):

1. Menyediakan integrasi yang efisien dan baik dari pilihan transportasi berkelanjutan.

2. Berfokus pada peningkatan pengalaman pengguna yang berbeda pilihan transportasi.

3. Menjamin keselamatan dan keamanan untuk semua pengguna transportasi.

4. Menciptakan suatu area yang efektif dengan placemaking strategi.

5. Memungkinkan adanya fleksibilitas untuk merangkul teknologi inovasi dan memupuk ketahanan.

6. Mengatasi keadilan dengan mempertimbangkan aksesibilitas dalam ketersediaan pilihan transportasi yang berbeda lingkungan.

7. Menciptakan peluang untuk membentuk kemitraan yang efektif.

\section{Pejalan Kaki}

Secara harafiah, pejalan kaki berarti orang yang berjalan di jalan. Pedestrian adalah setiap manusia yang memiliki kaki atau yang menggunakan kursi roda atau sarana angkut yang didorong oleh tenaga manusia selain sepeda (Kaliongga, Kumurur, \& Sembel, 2014). Pertimbangan dalam perencanaan kebutuhan pejalan kaki (New Jersey Department of Transportation, 2016) adalah asal dan tujuan pejalan kaki, lalu menempatkan akses, pejalan kaki akan memilih rute terpendek, mendata tata guna lahan, melihat keadaan sekitar kawasan, menghindari hal-hal yang mengganggu akses pejalan kaki. Karakteristik pejalan kaki (Suryani, 2006) adalah asal dan tujuan pergerakan berkaitan penggunaan lahan, kegiatan di ruang publik perkotaan, pola penggunaan lahan, dan penghubung.

\section{Jalur Pejalan Kaki}

Pedoman perencanaan yang ditetapkan Kementrian PUPR Tahun 2018 memenuhi aspek keterpaduan sistem, kontinuitas, keamanan, kenyamanan, aksesibilitas. Faktor pendukung jalur pejalan kaki yang diperlukan adalah tempat pemberhentian, fasilitas parkir, pelayanan umum, pemeliharaan fasilitas pejalan kaki, dll. Berikut adalah Pedoman Penyediaan Dan Pemanfaatan Prasarana Dan Sarana Ruang Pejalan Kaki Di Perkotaan berdasarkan Peraturan Menteri Pekerjaan Umum.

Tabel 1. Pedoman Penyediaan Dan Pemanfaatan Prasarana Dan Sarana Ruang Pejalan Kaki Di Perkotaan

\begin{tabular}{|c|c|c|c|c|}
\hline No. & Fasilitas & Keselamatan & Kenyamanan & Keindahan \\
\hline 1. & $\begin{array}{l}\text { Prasarana Ruang } \\
\text { Pejalan Kaki }\end{array}$ & $\begin{array}{l}\text { Ruang pejalan kaki terpisah } \\
\text { dari jalur lalu lintas } \\
\text { kendaraan serta memiliki } \\
\text { ketinggian yang berbeda. }\end{array}$ & $\begin{array}{l}\text { Jalur pejalan kaki memiliki } \\
\text { lebar yang nyaman dengan } \\
\text { minimal } 1,5 \mathrm{~m} \text {. }\end{array}$ & $\begin{array}{l}\text { Ruang pejalan kaki memiliki } \\
\text { material penutup tanah } \\
\text { yang berpola. }\end{array}$ \\
\hline 2. & Street Furniture & $\begin{array}{l}\text { Terletak pada titik-titik yang } \\
\text { aman dari lalu lintas } \\
\text { kendaraan. }\end{array}$ & $\begin{array}{l}\text { Tata letak fasilitas tidak } \\
\text { mengganggu jalur pejalan } \\
\text { kaki. }\end{array}$ & $\begin{array}{l}\text { Desain yang dapat mewakili } \\
\text { karakter dari lingkungan, } \\
\text { sehingga memiliki kualitas } \\
\text { estetikq yang baik. }\end{array}$ \\
\hline
\end{tabular}




\begin{tabular}{|c|c|c|c|c|}
\hline No. & Fasilitas & Keselamatan & Kenyamanan & Keindahan \\
\hline 3. & $\begin{array}{l}\text { Papan Informasi } \\
\text { (Signage) }\end{array}$ & $\begin{array}{l}\text { Terletak di titik-titik yang } \\
\text { nyaman dan terhindar dari } \\
\text { tindakan vandalisme. }\end{array}$ & $\begin{array}{l}\text { Tata letaknya tidak } \\
\text { menghambat jalur pejalan } \\
\text { kaki. }\end{array}$ & $\begin{array}{l}\text { Desain yang ada dapat } \\
\text { mewakili karakter lokal } \\
\text { lingkungan, sehingga } \\
\text { memiliki kualitas estetika } \\
\text { yang baik. }\end{array}$ \\
\hline 4. & $\begin{array}{l}\text { Ramp dan Marka } \\
\text { Penyandang } \\
\text { Disabilitas } \\
\text { (Diffable) }\end{array}$ & $\begin{array}{l}\text { Ramp dan marka diletakkan } \\
\text { pada lokasi yang aman dari } \\
\text { sirkulasi kendaraan. }\end{array}$ & $\begin{array}{l}\text { Jalur disabilitas dibedakan } \\
\text { dengan warna dan pola yang } \\
\text { sudah ditentukan. }\end{array}$ & $\begin{array}{l}\text { Memiliki penanda khusus } \\
\text { seperti pagar pembatas } \\
\text { ataupun garis berwarna. }\end{array}$ \\
\hline 5. & Jalur Hijau & $\begin{array}{l}\text { Terletak di antara jalur } \\
\text { pejalan kaki dan kendaraan. }\end{array}$ & $\begin{array}{l}\text { Memiliki vegetasi peneduh } \\
\text { pejalan kaki yang berguna } \\
\text { untuk penurun iklim mikro. }\end{array}$ & $\begin{array}{l}\text { Memiliki vegetasi dekoratif } \\
\text { yang dapat meningkatkan } \\
\text { nilai estetika ruang. }\end{array}$ \\
\hline 6. & Drainase & $\begin{array}{l}\text { Jaringan drainase tidak } \\
\text { boleh } \\
\text { permukaan ruang pejalan } \\
\text { kaki. }\end{array}$ & $\begin{array}{l}\text { Jaringan drainase harus } \\
\text { selalu terpelihara } \\
\text { kebersihannya sehingga } \\
\text { tidak mengganggu aktivitas } \\
\text { pejalan kaki. }\end{array}$ & $\begin{array}{l}\text { Material penutup pada } \\
\text { drainase harus selalu } \\
\text { dipelihara kebersihannya. }\end{array}$ \\
\hline
\end{tabular}

Sumber : Peraturan Menteri Pekerjaan Umum No. 30/PRT/M/2006

\section{Fasilitas Pejalan Kaki}

Terdapat dua fasilitas pejalan kaki yaitu (Tanan, Wibowo, \& Tinumbia, 2017) :

1. Fasilitas utama, yaitu jalur pedestrian

2. Fasilitas pendukung, seperti rambu, marka, papan informasi, dll.

Jalur perjalanan yang dapat dengan mudah dicapai oleh pejalan kaki merupakan suatu jalur yang tidak terputus, bebas hambatan, serta menghubungkan seluruh elemen dan ruang yang mudah dicapai.

\section{METODE}

Studi ini dilakukan di kawasan Blok M, Kecamatan Kebayoran Baru, Jakarta Selatan. Batas dengan kawasan studi diambil dari radius 400m Stasiun MRT Blok M dan Terminal Bus Blok M. Berikut adalah peta yang menggambarkan dari batasan masalah.

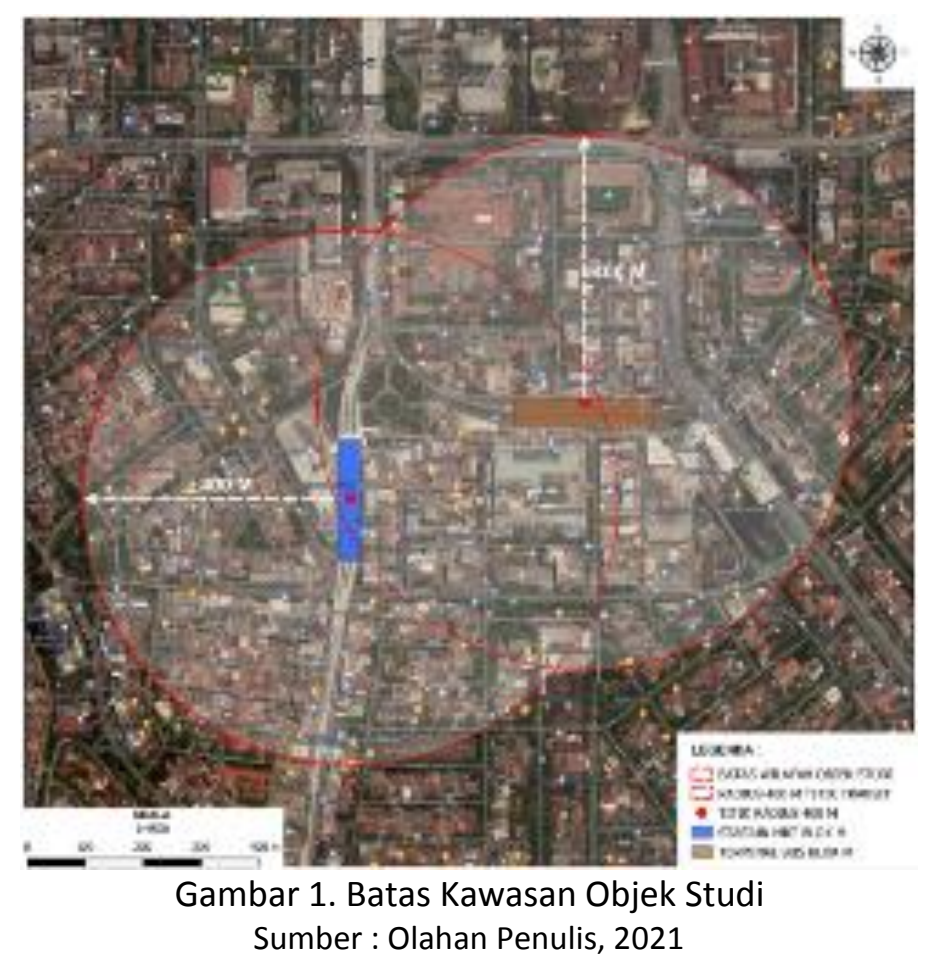


Data yang digunakan dalam studi berupa kondisi fisik kawasan (jalur pejalan kaki dan bangunan), dokumen RDTR 2030, dan PRK 2020. Kemudian terdapat juga data mengenai jumlah penumpang transportasi umum stasiun MRT dan terminal bus yang didapatkan dari PT MRT Jakarta, Dinas Perhubungan Jakarta, dan PT Transportasi Jakarta. Selanjutnya data juga didapatkan berdasarkan hasil penyebaran kuesioner yang dilakukan di kawasan Blok M. Terkait dengan data kondisi fisik kawasan dikumpulkan dengan menggunakan metode observasi atau survei lapangan untuk mendapatkan data eksisting yang bersifat aktual. Kemudian metode studi literatur serta pencarian melalui internet juga dilakukan dalam mendapatkan data serta menunjang studi ini. Data diolah dengan menggunakan metode pemetaan dengan menggunakan alat analisis QGIS dalam memberikan gambaran terkait kondisi fisik kawasan Blok M. Setelah itu peta yang ada diolah lebih lanjut dalam bentuk tabel dan diagram sehingga memudahkan analisis. Selain itu, dokumentasi juga ditambahkan untuk memberikan gambaran lebih lanjut dalam melakukan analisis.

Metode pendekatan yang digunakan dalam melakukan studi ini adalah pendekatan kualitatif dan kuantitatif. Pendekatan kualitatif digunakan untuk melihat profil dari penumpang di titik transit, mobilitas penumpang, kondisi jalur pejalan kaki, dan aktivitas pendukung di titik transit. Kemudian untuk pendekatan kuantitatif digunakan untuk melihat simulasi dari proyeksi jumlah penumpang berdasarkan RDTR 2030 dan PRK 2020. Dalam mencapai tujuan data yang sudah dikumpulkan dianalisis dengan menggunakan metode analisis deskriptif. Pembahasan awal dalam melakukan analisis ini berupa profil penumpang untuk memberikan gambaran profil dari penumpang yang ada di titik transit, data yang didapatkan berasal dari hasil penyebaran kuesioner. Selanjutnya melakukan analisis mobilitas penumpang untuk memberikan gambaran terkait dengan penumpang yang menggunakan transportasi umum dan melakukan transit. Analisis simulasi proyeksi penumpang berdasarkan RDTR 2030 membahas mengenai proyeksi jumlah penumpang apabila intensitas bangunan yang ada sesuai dengan RDTR. Melihat apakah dengan intensitas bangunan yang disesuaikan dengan RDTR mobilitas penumpang menjadi meningkat atau sebaliknya. Kemudian untuk analisis simulasi proyeksi penumpang berdasarkan PRK 2020, hampir sama dengan analisis sebelumnya hanya data yang digunakan berdasarkan PRK. Selanjutnya analisis kondisi jalur pejalan kaki membahas mengenai kondisi jalur pejalan kaki di titik transit yang digunakan oleh penumpang untuk melakukan perpindahan dari stasiun MRT ke terminal bus dan sebaliknya. Dan yang terakhir adalah analisis aktivitas pendukung di titik transit membahas mengenai aktivitas lingkungan yang ada di sekitar titik transit dengan melihat fungsi-fungsi komersial yang ada.

\section{DISKUSI DAN HASIL}

\section{Analisis Profil Penumpang di Titik Transit}

Berikut adalah diagram hasil penyebaran kuesioner yang telah dilakukan untuk menggambarkan profil penumpang di kawasan Blok M. 


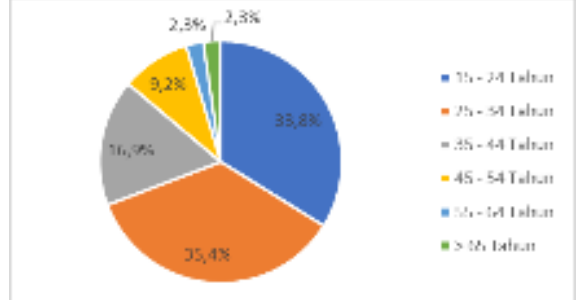

Gambar 2. Diagram Persentase Usia Sumber: Kuesioner, 2021

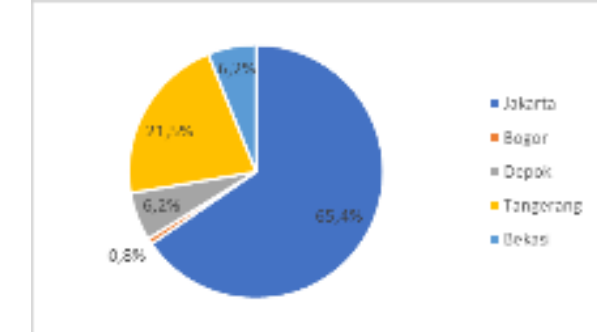

Gambar 4. Diagram Persentase Wilayah Tempat Tinggal

Sumber: Kuesioner, 2021

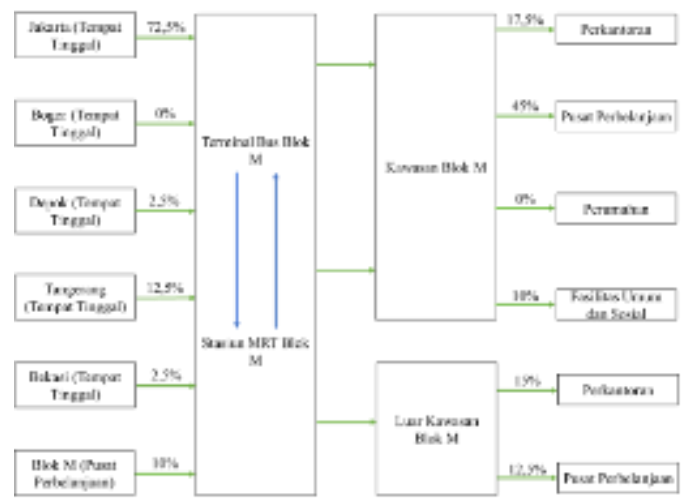

Gambar 6. Asal dan Tujuan Perjalanan Penumpang Siang Hari Sumber: Kuesioner, 2021

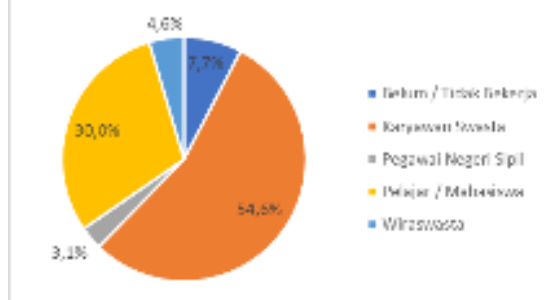

Gambar 3. Diagram Persentase Jenis Pekerjaan Sumber: Kuesioner, 2021

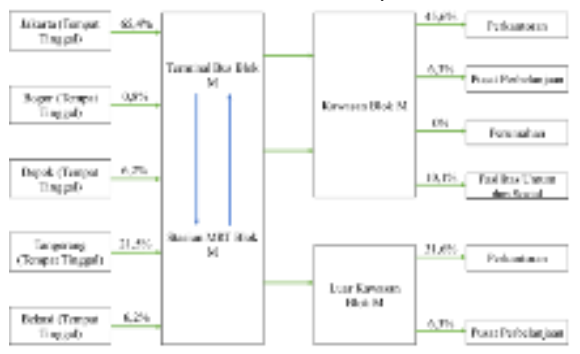

Gambar 5. Asal dan Tujuan Perjalanan Penumpang Pagi Hari Sumber: Kuesioner, 2021

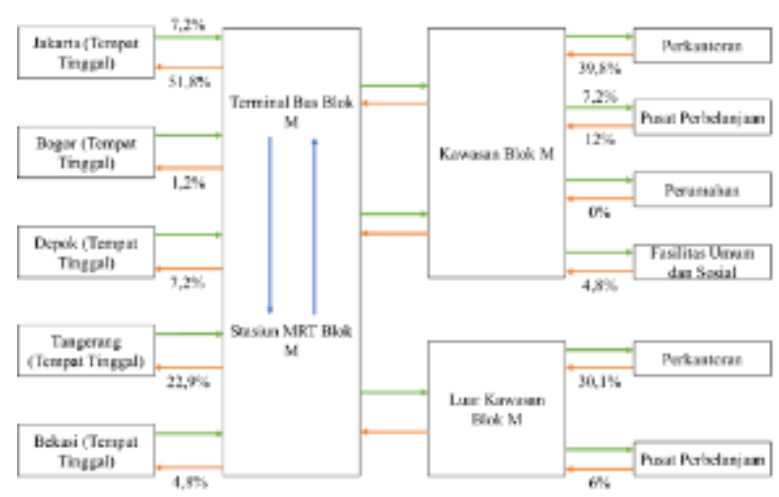

Gambar 7. Asal dan Tujuan Perjalanan

Penumpang Sore Hari Sumber: Kuesioner, 2021

Berdasarkan gambar diatas dapat dilihat bahwa mayoritas merupakan penumpang yang berusia 15 24 tahun dan 25 - 34 tahun dan dari jenis pekerjaan yang ada merupakan pelajar/mahasiswa dan karyawan swasta. Hal ini terjadi disebabkan kawasan Blok $\mathrm{M}$ yang merupakan pusat komersial yang terdapat pusat perbelanjaan, perkantoran seperti Menara Sentraya. Terdapat juga fasilitas umum dan sosial seperti sekolah yang merupakan tingkat SMA sehingga untuk skala tingkatan lebih luas. Karakteristik dari penumpang berdasarkan tempat tinggal didominasi oleh penumpang yang bertempat tinggal di Jakarta. Namun adapun responden yang tinggal di luar wilayah Jakarta. Hal ini terjadi disebabkan Terminal Bus Blok $\mathrm{M}$ terdapat bus yang melayani rute antar kota.

Asal dan tujuan perjalanan responden pada pagi hari berasal dari tempat tinggal mereka dengan tujuan menuju perkantoran, pusat perbelanjaan, dan fasilitas umum dan sosial. Hal ini menunjukkan bahwa pada pagi hari responden cenderung bergerak kearah pusat kota yang memiliki tingkat aktivitas yang tinggi. Kemudian untuk asal dan tujuan responden siang hari lebih didominasi oleh responden yang berasal dari tempat tinggal menuju pusat perbelanjaan yaitu sebanyak $57,5 \%$. Responden yang berasal dari pusat perbelanjaan Blok $\mathrm{M}$ menuju ke perkantoran di luar kawasan Blok $\mathrm{M}$ merupakan karyawan swasta. Selanjutnya untuk asal dan tujuan responden pukul $16.00-18.00$ didominasi oleh responden 
yang berasal perkantoran menuju ke tempat tinggal masing-masing sebanyak $69,9 \%$, sore hari merupakan waktu pulang kerja. Responden yang berasal dari tempat tinggal mereka menuju pusat perbelanjaan di Blok $M$ yaitu sebanyak $7,2 \%$, cenderung menuju ke tempat wisata yang ada seperti Little Tokyo, M Bloc, dan Blok M Plaza, aktivitas di kawasan tersebut lebih banyak pada saat malam hari.

\section{Analisis Mobilitas Penumpang}

Berdasarkan data jumlah pengunjung, rata-rata jumlah pengunjung transportasi umum sebelum pandemi COVID-19 mencapai 7.800 - 10.300 jiwa/hari. Rata-rata harian jumlah pengunjung saat pandemi COVID-19 mengalami penurunan yang signifikan mencapai $1.100-3.500$ jiwa/hari. Tren jumlah pengunjung yang ada di kawasan Blok $\mathrm{M}$ ini tidak jauh berbeda. Ketiga moda transportasi umum sama-sama mengalami penurunan yang signifikan mulai dari bulan Februari 2020 hingga bulan Mei 2020, disebabkan adanya pandemi COVID-19, pada saat itu diberlakukan Pembatasan Sosial Berskala Besar (PSBB).

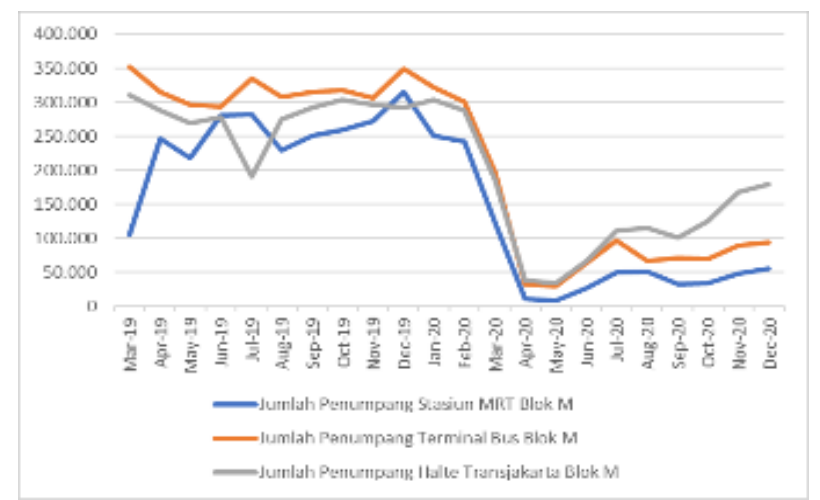

Gambar 8. Grafik Jumlah Pengunjung Transportasi Umum Kawasan Blok M Sumber: Olahan Penulis, 2021

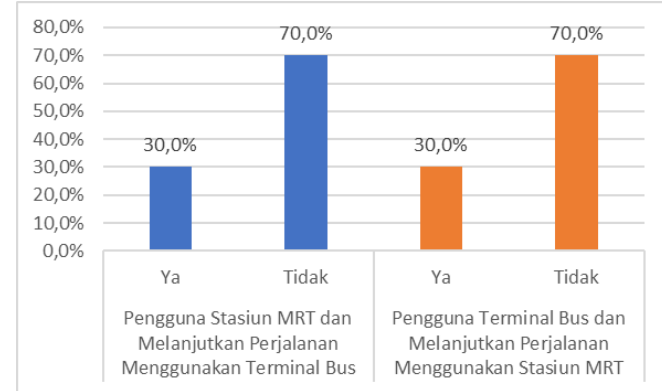

Gambar 9. Diagram Persentase Perpindahan Moda Transportasi Umum di Kawasan Blok M Sumber: Kuesioner, 2021

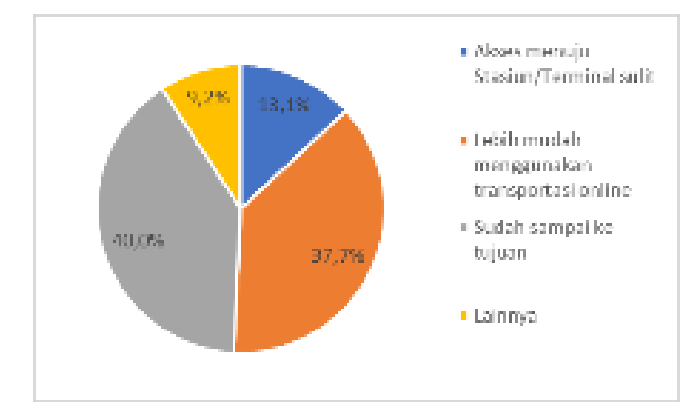

Gambar 10. Diagram Persentase Alasan Responden Tidak Melakukan Perpindahan Moda Transportasi Sumber: Kuesioner, 2021

Penumpang yang melakukan perpindahan antara stasiun dan terminal sebesar $30 \%$. Mobilitas yang ada di kawasan Blok $\mathrm{M}$ ini belum maksimal disebabkan akses dalam melakukan perpindahan antar moda transportasi belum tersedia dengan baik. Kawasan Blok $M$ Square merupakan akses yang paling sering dilewati, disebabkan kondisi akses jauh lebih baik dibandingkan dengan yang melewati Taman Martha Tiahahu. Walaupun, akses ini tidak langsung menghubungkan ke terminal bus sehingga terdapat pejalan kaki yang melewati Taman Martha Tiahahu.

Sebanyak $40 \%$ responden tidak melakukan perpindahan moda transportasi umum disebabkan responden yang memang tujuan perjalanan menuju kawasan Blok M. Responden yang menjawab lainnya yaitu responden menggunakan kendaraan pribadi, dan melanjutkan perjalanan dengan menggunakan Transjakarta. Terdapat kesamaan terkait rute perjalanan Transjakarta dan MRT, 
sehingga responden akan lebih memilih yang praktis dan dekat dibandingkan harus melakukan perpindahan moda. Kemudian untuk akses menuju stasiun atau terminal sulit, hal tersebut disebabkan antara stasiun MRT dengan terminal bus belum terhubung langsung, sedangkan pejalan kaki tentunya cenderung lebih memilih hal yang praktis dan mudah. Hal ini disebabkan belum ada jembatan penyebrangan yang menghubungkan langsung antara stasiun MRT dengan terminal bus. Dalam meningkatkan mobilitas penumpang, perlu memperbaiki akses dalam perpindahan moda dengan mempercepat pembangunan JPO yang menghubungkan langsung antara stasiun dengan terminal.

\section{Analisis Proyeksi Penumpang Berdasarkan RDTR 2030}

Berikut adalah simulasi mengenai asumsi jumlah penumpang transportasi umum yang telah dilakukan. Persentase asumsi jumlah penumpang ini didapatkan dari hasil survey yang dibuat oleh Masyarakat Transportasi Indonesia (MTI) Pengguna Transportasi Umum Sebelum COVID-19.

Tabel 2. Asumsi Jumlah Penumpang Berdasarkan RDTR 2030

\begin{tabular}{|c|c|c|c|c|c|c|c|c|c|}
\hline \multirow{3}{*}{ Blok } & \multirow{3}{*}{$\begin{array}{l}\text { Sub } \\
\text { Blok }\end{array}$} & \multicolumn{3}{|c|}{ Asumsi Jumlah Penumpang } & \multirow{3}{*}{$\begin{array}{c}\text { Total } \\
\text { Jumlah } \\
\text { Penumpang } \\
\text { (Jiwa) }\end{array}$} & \multicolumn{3}{|c|}{ Asumsi Jumlah Penumpang } & \multirow{3}{*}{$\begin{array}{c}\text { Total } \\
\text { Jumlah } \\
\text { Penumpang } \\
\text { (Jiwa) }\end{array}$} \\
\hline & & $\begin{array}{c}\text { High } \\
\text { Income }\end{array}$ & $\begin{array}{l}\text { Middle } \\
\text { Income }\end{array}$ & $\begin{array}{c}\text { Low } \\
\text { Income }\end{array}$ & & $\begin{array}{c}\text { High } \\
\text { Income }\end{array}$ & $\begin{array}{l}\text { Middle } \\
\text { Income }\end{array}$ & $\begin{array}{c}\text { Low } \\
\text { Income }\end{array}$ & \\
\hline & & $0 \%$ & $25 \%$ & $75 \%$ & & $0 \%$ & $25 \%$ & $75 \%$ & \\
\hline \multicolumn{2}{|c|}{$\begin{array}{c}\text { Pemerintahan } \\
\text { Nasional }\end{array}$} & \multicolumn{4}{|c|}{$10 \mathrm{~m} 2$} & \multicolumn{4}{|c|}{$11 \mathrm{~m} 2$} \\
\hline \multirow{2}{*}{01} & 001 & - & 745 & 2.598 & 3.343 & - & 677 & 2.362 & 3.039 \\
\hline & 007 & - & 160 & 558 & 718 & - & 145 & 507 & 653 \\
\hline 04 & 021 & - & 574 & 2.004 & 2.578 & - & 522 & 1.822 & 2.344 \\
\hline \multicolumn{2}{|c|}{ Total (Jiwa) } & - & 1.479 & 5.160 & 6.639 & - & 1.345 & 4.691 & 6.036 \\
\hline \multicolumn{2}{|c|}{ Perkantoran } & \multicolumn{4}{|c|}{$10 \mathrm{~m} 2$} & \multicolumn{4}{|c|}{$18 \mathrm{~m} 2$} \\
\hline 01 & 014 & - & 15 & 54 & 69 & - & 9 & 30 & 39 \\
\hline \multirow{9}{*}{02} & 004 & - & 240 & 837 & 1.077 & - & 133 & 465 & 598 \\
\hline & 005 & - & 199 & 693 & 892 & - & 110 & 385 & 495 \\
\hline & 006 & - & 80 & 279 & 359 & - & 44 & 155 & 199 \\
\hline & 007 & - & 77 & 270 & 347 & - & 43 & 150 & 193 \\
\hline & 008 & - & 144 & 504 & 648 & - & 80 & 280 & 360 \\
\hline & 010 & - & 186 & 648 & 834 & - & 103 & 360 & 463 \\
\hline & 012 & - & 237 & 828 & 1.065 & - & 132 & 460 & 592 \\
\hline & 013 & - & 1.121 & 3.911 & 5.032 & - & 623 & 2.173 & 2.795 \\
\hline & 014 & - & 191 & 666 & 857 & - & 106 & 370 & 476 \\
\hline 04 & 048 & - & 19 & 65 & 83 & - & 10 & 36 & 46 \\
\hline \multicolumn{2}{|c|}{ Total (Jiwa) } & - & 2.510 & 8.754 & 11.264 & - & 1.394 & 4.864 & 6.258 \\
\hline \multicolumn{2}{|c|}{$\begin{array}{c}\text { Perdagangan } \\
\text { dan Jasa }\end{array}$} & \multicolumn{4}{|c|}{$10 \mathrm{~m} 2$} & \multicolumn{4}{|c|}{$10 \mathrm{~m} 2$} \\
\hline 02 & 009 & - & 708 & 2.470 & 3.178 & - & 708 & 2.470 & 3.178 \\
\hline \multirow{2}{*}{04} & 023 & - & 446 & 1.555 & 2.001 & - & 446 & 1.555 & 2.001 \\
\hline & 032 & - & 12 & 43 & 56 & - & 12 & 43 & 56 \\
\hline \multicolumn{2}{|c|}{ Total (Jiwa) } & - & 1.166 & 4.068 & 5.234 & - & 1.166 & 4.068 & 5.234 \\
\hline \multicolumn{10}{|c|}{ Total Jumlah } \\
\hline \multicolumn{2}{|c|}{$\begin{array}{l}\text { Penumpang } \\
\text { (Jiwa) }\end{array}$} & - & 5.155 & 17.982 & 23.137 & - & 3.905 & 13.622 & 17.527 \\
\hline
\end{tabular}

Sumber : Masyarakat Transportasi Indonesia dan Olahan Penulis, 2021 


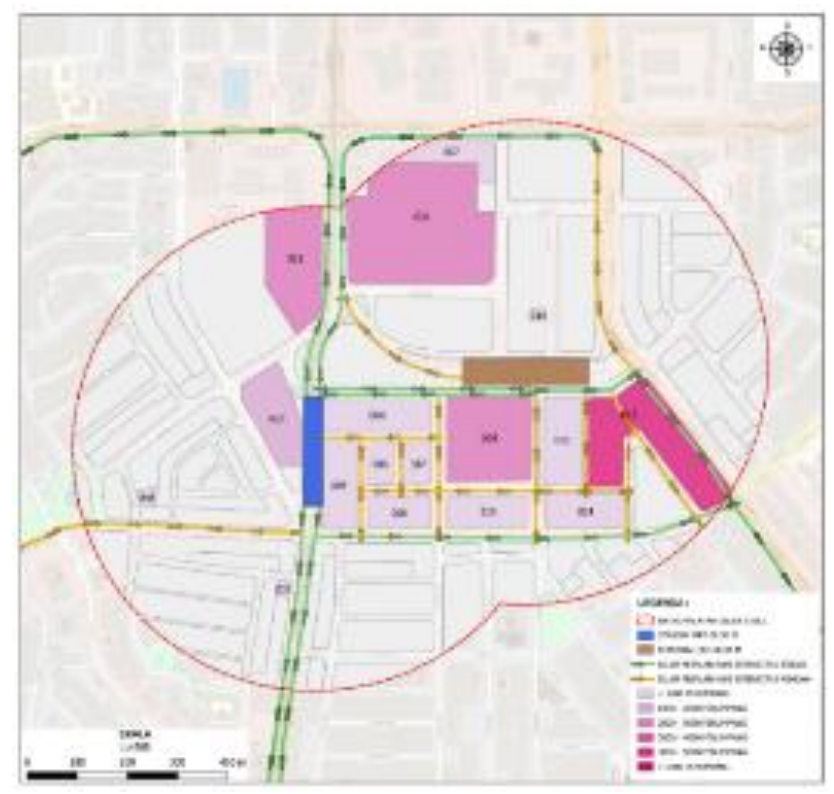

Gambar 11. Peta Asumsi Jumlah Penumpang Berdasarkan RDTR 2030 Sumber: Olahan Penulis, 2021

Akan terjadi penambahan jumlah penumpang yaitu sebanyak 23.137 jiwa apabila menggunakan standar kebutuhan ruang yang sama. Terjadi penambahan jumlah penumpang yaitu sebanyak 17.527 jiwa apabila standar kebutuhan ruang yang ada disesuaikan dengan fungsi bangunan yang ada. Dapat dilihat juga bahwa jumlah penumpang nantinya akan didominasi oleh penumpang yang berasal dari perkantoran. Apabila KLB yang ada di RDTR diterapkan di kawasan Blok M, maka akan menjadi potensi untuk kawasan Blok $\mathrm{M}$ disebabkan penambahan jumlah penumpang transportasi umum yang meningkat hampir $2 x$ lipat dibandingkan dengan rata-rata jumlah pengunjung sebelum pandemi COVID-19. Sub blok 013 yang akan menjadi potensial jumlah penumpang terbanyak disebabkan KLB yang tergolong tinggi dibandingkan dengan sub blok lainnya. Jalur pejalan kaki yang akan lebih banyak dilewati merupakan jalur pejalan kaki Jl. Panglima Polim, Jl. Melawai Raya dan Jl. Sultan Hasanudin.

\section{Analisis Simulasi Proyeksi Penumpang Berdasarkan PRK 2020}

Berikut adalah simulasi mengenai asumsi jumlah penumpang transportasi umum yang telah dilakukan. Persentase asumsi jumlah penumpang ini didapatkan dari hasil survey yang dibuat oleh Masyarakat Transportasi Indonesia (MTI) Pengguna Transportasi Umum Sebelum COVID-19.

Tabel 3. Asumsi Jumlah Penumpang Berdasarkan PRK 2020

\begin{tabular}{|c|c|c|c|c|c|c|c|c|c|}
\hline \multirow{3}{*}{ Blok } & \multirow{3}{*}{$\begin{array}{l}\text { Sub } \\
\text { Blok }\end{array}$} & \multicolumn{3}{|c|}{ Asumsi Jumlah Penumpang } & \multirow{3}{*}{$\begin{array}{c}\text { Total } \\
\text { Jumlah } \\
\text { Penumpang } \\
\text { (Jiwa) }\end{array}$} & \multicolumn{3}{|c|}{ Asumsi Jumlah Penumpang } & \multirow{3}{*}{$\begin{array}{c}\text { Total } \\
\text { Jumlah } \\
\text { Penumpang } \\
\text { (Jiwa) }\end{array}$} \\
\hline & & $\begin{array}{c}\text { High } \\
\text { Income }\end{array}$ & $\begin{array}{l}\text { Middle } \\
\text { Income }\end{array}$ & $\begin{array}{c}\text { Low } \\
\text { Income }\end{array}$ & & $\begin{array}{c}\text { High } \\
\text { Income }\end{array}$ & $\begin{array}{l}\text { Middle } \\
\text { Income }\end{array}$ & $\begin{array}{c}\text { Low } \\
\text { Income }\end{array}$ & \\
\hline & & $0 \%$ & $25 \%$ & $75 \%$ & & $0 \%$ & $25 \%$ & $75 \%$ & \\
\hline \multicolumn{2}{|c|}{$\begin{array}{c}\text { Pemerintahan } \\
\text { Nasional }\end{array}$} & \multicolumn{4}{|c|}{$10 \mathrm{~m} 2$} & \multicolumn{4}{|c|}{$11 \mathrm{~m} 2$} \\
\hline \multirow{2}{*}{01} & 001 & - & 2.420 & 8.444 & 10.864 & - & 2.200 & 7.676 & 9.876 \\
\hline & 007 & - & 347 & 1.209 & 1.556 & - & 315 & 1.099 & 1.414 \\
\hline 04 & 021 & - & 402 & 1.403 & 1.805 & - & 366 & 1.275 & 1.641 \\
\hline \multicolumn{2}{|c|}{ Total (Jiwa) } & - & 3.169 & 11.055 & 14.224 & - & 2.881 & 10.050 & 12.931 \\
\hline \multicolumn{2}{|c|}{ Perkantoran } & \multicolumn{4}{|c|}{$10 \mathrm{~m} 2$} & \multicolumn{4}{|c|}{$18 \mathrm{~m} 2$} \\
\hline 01 & 014 & - & 18 & 63 & 81 & - & 10 & 35 & 45 \\
\hline 02 & 004 & - & 520 & 1.814 & 2.333 & - & 289 & 1.008 & 1.296 \\
\hline
\end{tabular}




\begin{tabular}{|c|c|c|c|c|c|c|c|c|c|}
\hline \multirow{3}{*}{ Blok } & \multirow{3}{*}{$\begin{array}{l}\text { Sub } \\
\text { Blok }\end{array}$} & \multicolumn{3}{|c|}{ Asumsi Jumlah Penumpang } & \multirow{3}{*}{$\begin{array}{c}\text { Total } \\
\text { Jumlah } \\
\text { Penumpang } \\
\text { (Jiwa) }\end{array}$} & \multicolumn{3}{|c|}{ Asumsi Jumlah Penumpang } & \multirow{3}{*}{$\begin{array}{c}\text { Total } \\
\text { Jumlah } \\
\text { Penumpang } \\
\text { (Jiwa) }\end{array}$} \\
\hline & & \multirow{2}{*}{$\begin{array}{c}\begin{array}{c}\text { High } \\
\text { Income }\end{array} \\
0 \%\end{array}$} & \multirow{2}{*}{$\begin{array}{c}\begin{array}{c}\text { Middle } \\
\text { Income }\end{array} \\
25 \% \\
\end{array}$} & \multirow{2}{*}{$\begin{array}{c}\begin{array}{c}\text { Low } \\
\text { Income }\end{array} \\
75 \%\end{array}$} & & \multirow{2}{*}{$\begin{array}{c}\begin{array}{c}\text { High } \\
\text { Income }\end{array} \\
0 \% \\
\end{array}$} & \multirow{2}{*}{$\begin{array}{c}\begin{array}{c}\text { Middle } \\
\text { Income }\end{array} \\
25 \% \\
\end{array}$} & \multirow{2}{*}{$\begin{array}{c}\begin{array}{c}\text { Low } \\
\text { Income }\end{array} \\
75 \%\end{array}$} & \\
\hline & & & & & & & & & \\
\hline & 005 & - & 430 & 1.502 & 1.932 & - & 239 & 834 & 1.073 \\
\hline & 006 & - & 120 & 419 & 538 & - & 67 & 233 & 299 \\
\hline & 007 & - & 116 & 405 & 521 & - & 65 & 225 & 290 \\
\hline & 008 & - & 217 & 756 & 973 & - & 120 & 420 & 540 \\
\hline & 010 & - & 279 & 972 & 1.251 & - & 155 & 540 & 695 \\
\hline & 012 & - & 356 & 1.242 & 1.598 & - & 198 & 690 & 888 \\
\hline & 013 & - & 1.325 & 4.622 & 5.946 & - & 736 & 2.568 & 3.304 \\
\hline & 014 & - & 286 & 999 & 1.285 & - & 159 & 555 & 714 \\
\hline 04 & 048 & - & 22 & 76 & 97 & - & 12 & 42 & 54 \\
\hline \multicolumn{2}{|c|}{ Total (Jiwa) } & - & 3.689 & 12.868 & 16.556 & - & 2.049 & 7.149 & 9.198 \\
\hline \multicolumn{2}{|c|}{$\begin{array}{c}\text { Perdagangan } \\
\text { dan Jasa }\end{array}$} & \multicolumn{4}{|c|}{$10 \mathrm{~m} 2$} & \multicolumn{4}{|c|}{$10 \mathrm{~m} 2$} \\
\hline 02 & 009 & - & 1.096 & 3.822 & 4.918 & - & 1.096 & 3.822 & 4.918 \\
\hline \multirow{2}{*}{04} & 023 & - & 604 & 2.106 & 2.710 & - & 604 & 2.106 & 2.710 \\
\hline & 032 & - & 23 & 81 & 104 & - & 23 & 81 & 104 \\
\hline \multicolumn{2}{|c|}{ Total (Jiwa) } & - & 1.723 & 6.009 & 7.732 & - & 1.723 & 6.009 & 7.732 \\
\hline \multicolumn{2}{|c|}{ Total Jumlah } & & & & & & & & \\
\hline \multicolumn{2}{|c|}{$\begin{array}{l}\text { Penumpang } \\
\text { (Jiwa) }\end{array}$} & - & 8.580 & 29.932 & 38.512 & - & 6.653 & 23.208 & 29.861 \\
\hline
\end{tabular}

Sumber : Masyarakat Transportasi Indonesia dan Olahan Penulis, 2021

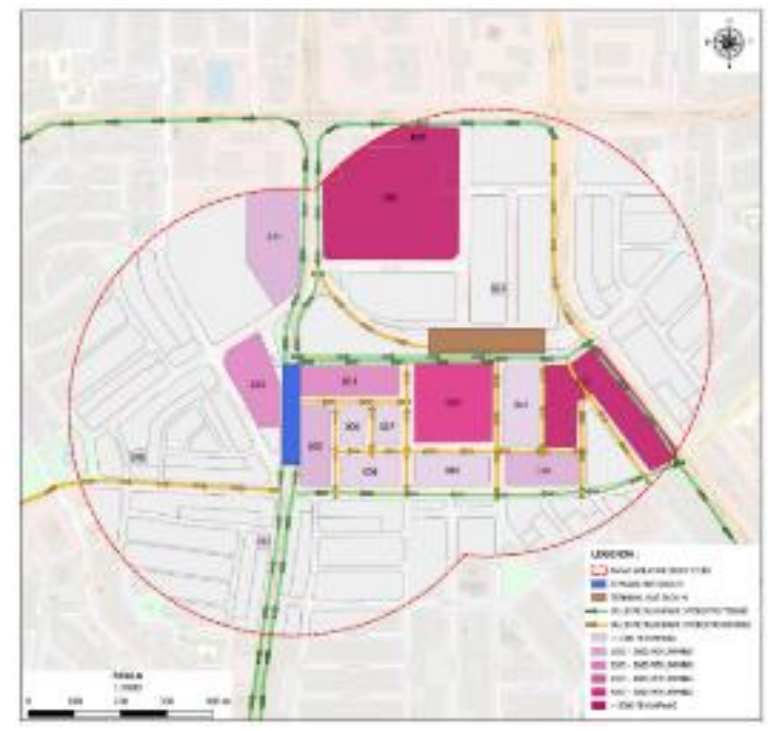

Gambar 12. Peta Asumsi Jumlah Penumpang Berdasarkan PRK 2020 Sumber: Olahan Penulis, 2021

Akan terjadi penambahan jumlah penumpang yaitu sebanyak 38.512 jiwa apabila menggunakan standar kebutuhan ruang yang sama. Terjadi penambahan jumlah penumpang yaitu sebanyak 29.861 jiwa apabila standar kebutuhan ruang yang ada disesuaikan dengan fungsi bangunan yang ada. Peningkatan jumlah penumpang ini hampir $2 x$ lipat dari peningkatan jumlah penumpang dari simulasi menggunakan data RDTR 2030, disebabkan perbandingan data KLB antara RDTR 2030 dengan PRK 2020 yang cukup signifikan berbeda. Sub blok 001, 007 dan 013 yang akan menjadi potensial jumlah 
penumpang terbanyak disebabkan KLB yang tergolong tinggi dibandingkan dengan sub blok lainnya.

Berikut adalah mengenai simulasi proyeksi penumpang berdasarkan pengembangan kawasan Blok M. Berdasarkan PRK Tahun 2020, pengembangan kawasan Blok M terbagi menjadi tiga tahap yaitu, untuk tahap pertama pengembangan persil di dekat stasiun, tahap kedua yang merupakan jangka pendek, dan yang terakhir adalah tahap ketiga, pengembangan jangka panjang dilakukan mengkoordinasikan peluang pengembangan dengan area sekitar stasiun MRT. Berdasarkan simulasi pertambahan jumlah penumpang dapat dilihat bahwa terjadi peningkatan jumlah penumpang yang signifikan mulai dari tahap satu menuju tahap dua dan tahap tiga, disebabkan pengembangan tahap dua dan tahap tiga lebih banyak bila dibandingkan dengan pengembangan di tahap satu.

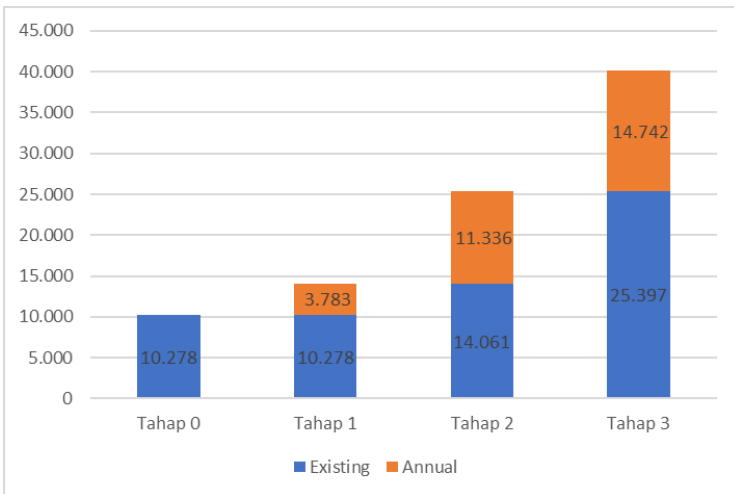

Gambar 13. Simulasi Peningkatan Jumlah Penumpang Berdasarkan Pengembangan Kawasan Blok M

Sumber : PT MRT Jakarta, dan Olahan Penulis, 2021

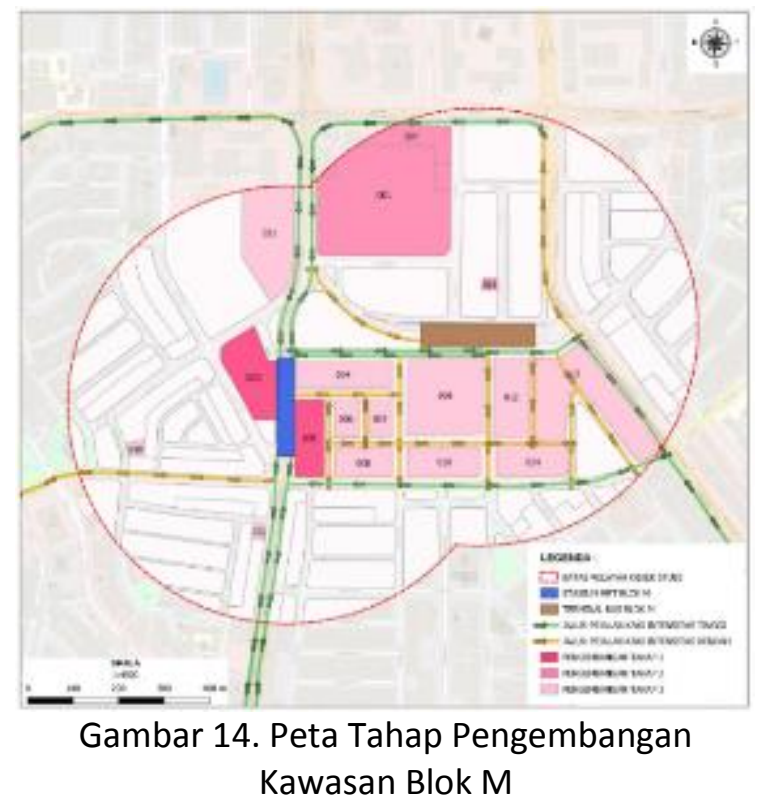

Sumber : PT MRT Jakarta, dan Olahan Penulis, 2021

\section{Analisis Kondisi Jalur Pejalan Kaki}

Berikut adalah skoring jalur pejalan kaki kawasan Blok $\mathrm{M}$ berdasarkan Peraturan Menteri Pekerjaan Umum No. 30/PRT/M/2006.

Tabel 4. Skoring Jalur Pejalan Kaki Berdasarkan Peraturan Menteri Pekerjaan Umum

\begin{tabular}{|c|c|c|c|c|c|c|c|c|c|c|}
\hline \multirow{3}{*}{ No. } & \multirow{3}{*}{ Fasilitas } & \multicolumn{9}{|c|}{ Jalur Pejalan Kaki } \\
\hline & & \multicolumn{3}{|c|}{$\begin{array}{c}\text { Stasiun MRT Blok } \\
\text { M } \\
\end{array}$} & \multicolumn{3}{|c|}{$\begin{array}{c}\text { Kawasan Blok M } \\
\text { Square }\end{array}$} & \multicolumn{3}{|c|}{ Terminal Bus Blok $\mathrm{M}$} \\
\hline & & Ks & Kn & Ki & Ks & Kn & $\mathbf{K i}$ & Ks & Kn & Ki \\
\hline 1. & Prasarana Ruang Pejalan Kaki & 1 & 1 & 1 & 1 & 1 & 1 & 1 & 0 & 1 \\
\hline 2. & Tersedia Street Furniture & 0 & 0 & 0 & 0 & 0 & 0 & 0 & 0 & 0 \\
\hline 3. & Papan Informasi (Signage) & 1 & 1 & 1 & 1 & 1 & 1 & 0 & 0 & 0 \\
\hline 4. & $\begin{array}{l}\text { Ramp dan Marka Penyandang } \\
\text { Disabilitas (Diffable) }\end{array}$ & 1 & 1 & 1 & 0 & 1 & 1 & 0 & 0 & 0 \\
\hline 5. & Jalur Hijau & 1 & 1 & 1 & 0 & 1 & 0 & 0 & 1 & 0 \\
\hline 6. & Drainase & 1 & 1 & 1 & 1 & 1 & 1 & 1 & 1 & 1 \\
\hline & Total Skor & 5 & 5 & 5 & 3 & 5 & 4 & 2 & 2 & 2 \\
\hline
\end{tabular}

Keterangan :

Ks $=$ Keselamatan

$\mathrm{Kn}=$ Kenyamanan

$\mathrm{Ki}=$ Keindahan

Sumber : Peraturan Menteri Pekerjaan Umum No. 30/PRT/M/2006 
Jalur pejalan kaki di Stasiun MRT Blok M merupakan jalur pejalan kaki yang mendapatkan skor tertinggi. Jalur pejalan kaki di kawasan Blok M Square dan Terminal Bus kurang ramah bagi penyandang disabilitas, guiding block dan ramp belum tersedia di seluruh jalur. Belum tersedia fasilitas pendukung seperti tempat duduk, tempat sampah, peneduh di ketiga jalur pejalan kaki. Ditemukan konflik di jalur pejalan kaki dan hambatan yang mengurangi rasa keamanan pejalan kaki seperti pengguna kendaraan bermotor yang menggunakan jalur pejalan kaki, parkir kendaraan bermotor, dan adanya pedagang kaki lima di jalur pejalan kaki. Jalur hijau yang ada juga belum tersedia di seluruh jalur pejalan kaki.

Hal ini yang perlu menjadi perhatian bagi pemerintah dan pengelola kawasan untuk menyediakan fasilitas pejalan kaki dan melakukan perbaikan sehingga keselamatan dan kenyamanan pejalan kaki ini terjamin terutama yang berada di kawasan Blok M Square dan Terminal Bus Blok M. Hal yang dapat dilakukan untuk meningkatkan keselamatan, kenyamanan pejalan kaki seperti :

1. Melakukan perbaikan jalur pejalan kaki yang rusak.

2. Melakukan penertiban di kawasan jalur pejalan kaki agar tidak terjadi konflik antara pejalan kaki dan pengguna kendaraan pribadi.

3. Menyediakan ramp dan jalur penyandang disabilitas.

4. Menyediakan fasilitas pendukung bagi pejalan kaki.

5. Melakukan pelebaran jalur pejalan kaki yang berada di kawasan Terminal Bus Blok M.

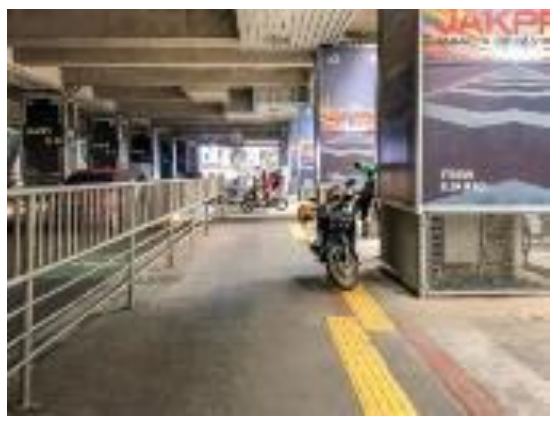

Gambar 15. Tidak tersedia street furniture dan terdapat kendaraan bermotor di stasiun MRT Sumber: Dokumentasi, 2021

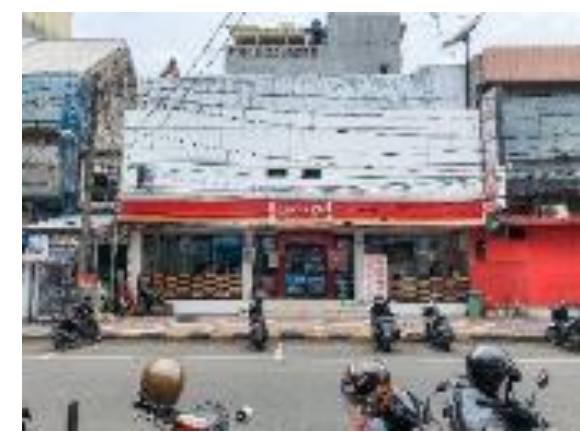

Gambar 17. Tidak tersedia jalur hijau di jalur pejalan kaki Blok M Square Sumber: Dokumentasi, 2021

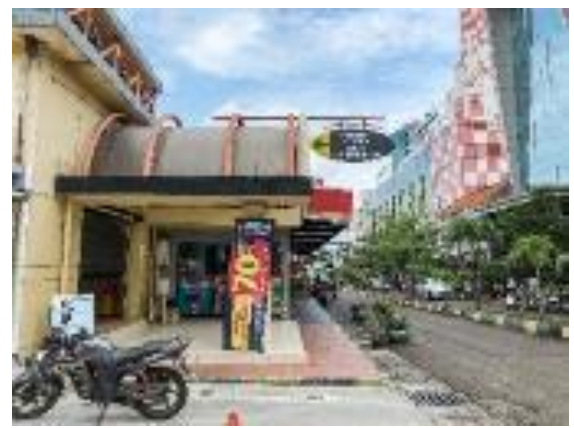

Gambar 16. Tidak tersedia ramp dan guiding block di jalur pejalan kaki Blok M Square Sumber: Dokumentasi, 2021

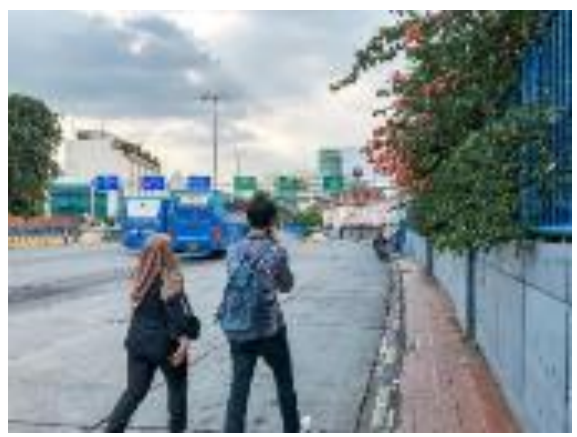

Gambar 18. Lebar pejalan kaki kurang dari 1,5m di Terminal Bus Blok M

Sumber: Dokumentasi, 2021 


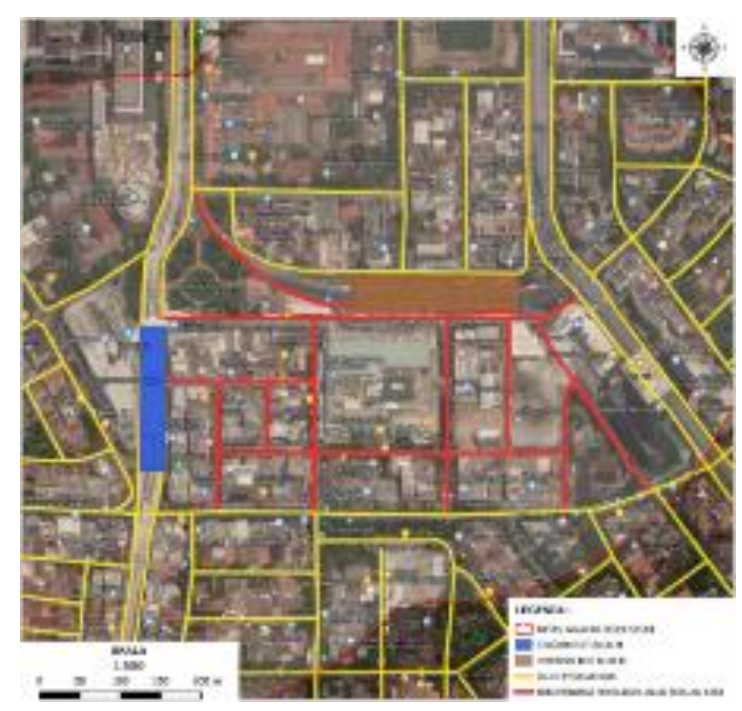

Gambar 19. Peta Rekomendasi Perbaikan Jalur Pejalan Kaki Sumber: Olahan Penulis, 2021

\section{Analisis Aktivitas Pendukung}

Berikut adalah peta yang menggambarkan aktivitas pendukung yang ada di kawasan Blok M.

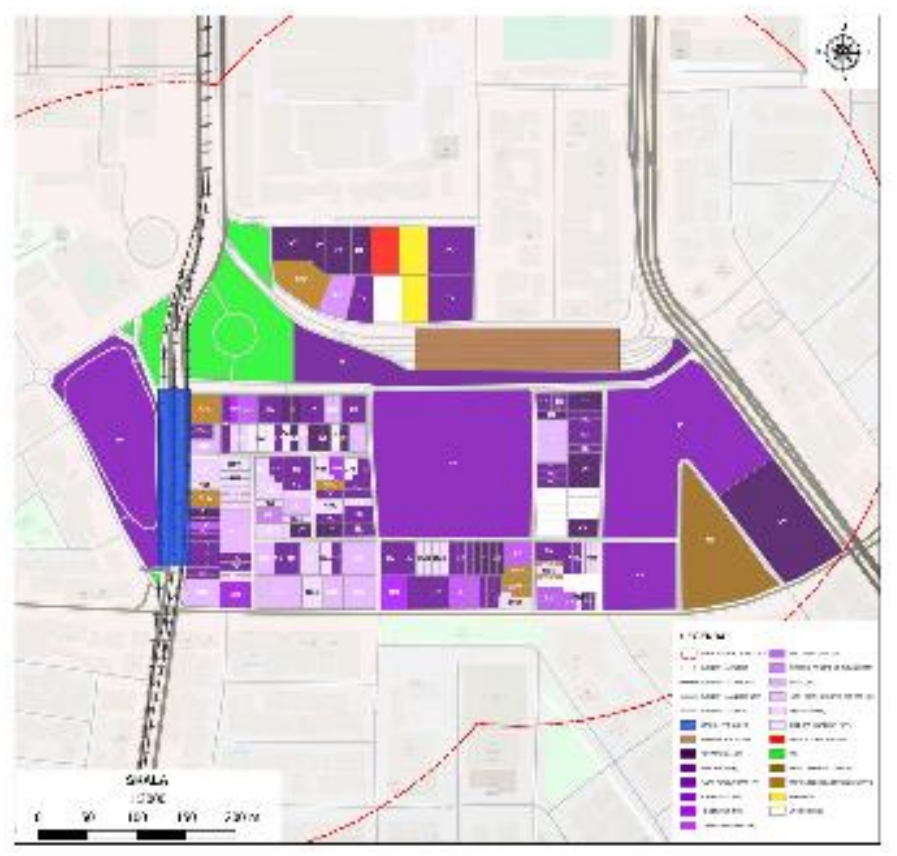

Gambar 20. Peta Fungsi Komersial Mikro

Sumber: Olahan Penulis, 2021 


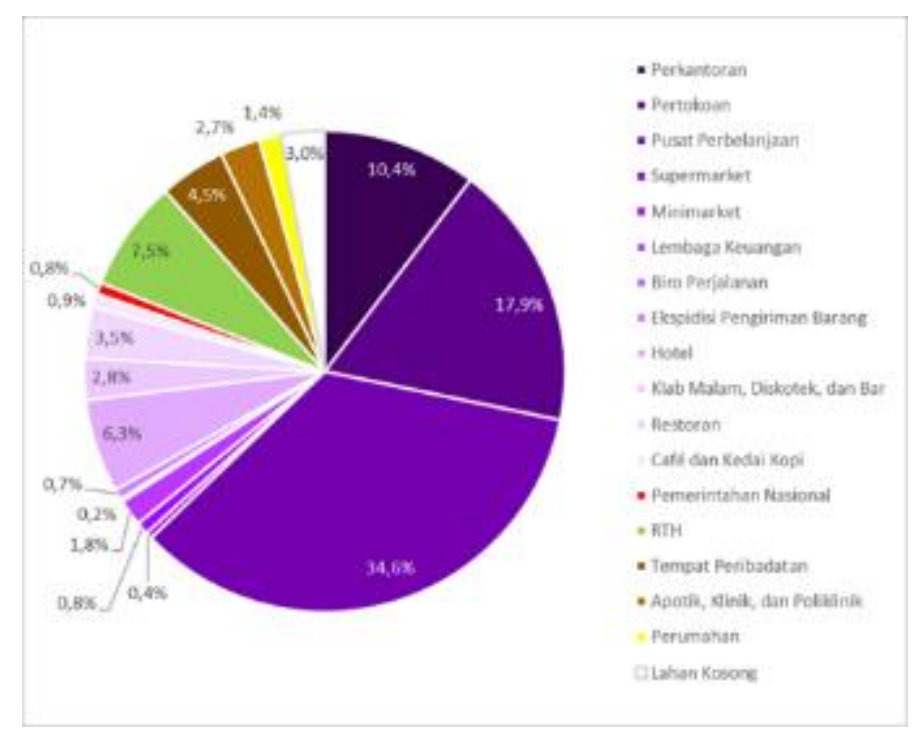

Gambar 21. Persentase Fungsi Komersial Mikro Sumber: Olahan Penulis, 2021

Aktivitas pendukung yang paling mendominasi dari kawasan Blok $\mathrm{M}$ eksisting saat ini adalah pusat perbelanjaan, dan yang kedua merupakan pertokoan. Terdapat juga perkantoran dan perhotelan, dimana selain menjadi pusat komersial, kawasan Blok $M$ juga merupakan tempat wisata. Dimana berdasarkan teori yang ada untuk aktivitas pendukung yang ada di kawasan Blok $\mathrm{M}$ sudah mencakup semua hal yang dibutuhkan. Sub blok yang ada juga berpotensial untuk dilewati baik oleh penumpang maupun wisatawan bila nantinya akan ada peningkatan KLB di kawasan Blok M. Hal ini akan membuat kawasan Blok $\mathrm{M}$ menjadi lebih berkembang, tingkat produktivitas menjadi tinggi dan dapat menarik masyarakat untuk datang ke kawasan ini.

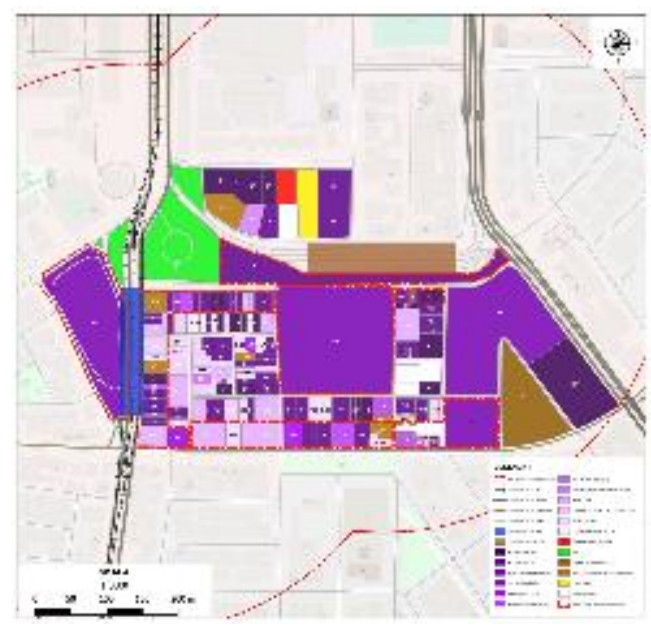

Gambar 22. Peta Sub Blok Yang Potensial Dilewati

Sumber: Olahan Penulis, 2021

Berdasarkan RDTR 2030 dan PRK 2020, kawasan Blok M kedepannya akan menjadi pusat komersial yang didominasi oleh kawasan perkantoran. Kemudian juga akan terdapat retail, dimana hal ini menjadi potensi untuk kawasan Blok $M$ dalam menarik wisatawan. Kawasan Blok $M$ perlu mempercepat tahap pengembangan yang sudah ada dalam PRK 2020. Sehingga dengan mempercepat tahap pengembangan kawasan ini diharapkan dapat menjadi daya tarik masyarakat untuk berkunjung, berjalan, dan menggunakan moda transportasi di kawasan ini. 


\section{KESIMPULAN DAN SARAN}

\section{Kesimpulan}

Dari studi yang telah dilakukan dapat disimpulkan bahwa mobilitas penumpang yang ada di kawasan Blok $\mathrm{M}$ ini hanya $30 \%$ penumpang yang melakukan perpindahan moda transportasi antara stasiun dengan terminal dan sisanya tidak melakukan perpindahan moda transportasi disebabkan alasan yang paling mendominasi adalah sudah sampai ke tujuan dan lebih mudah menggunakan transportasi online. Berdasarkan simulasi proyeksi penumpang baik berdasarkan RDTR 2030 maupun PRK 2020, dapat dilihat bahwa jika nantinya terdapat kenaikan KLB, maka hal ini menjadi potensi yang besar bagi kawasan Blok $\mathrm{M}$ disebabkan jumlah penumpang meningkat signifikan dibandingkan dengan rata-rata harian jumlah pengunjung pada saat sebelum COVID-19.

Kemudian terdapat beberapa kriteria yang belum terpenuhi untuk kondisi jalur pejalan kaki yang ada di kawasan Blok M. Terutama terkait masih adanya konflik yang terjadi antara pejalan kaki dengan pengguna kendaraan pribadi. Masih sering ditemukannya kendaraan bermotor yang menggunakan jalur pejalan kaki sebagai tempat parkir dan jalan kendaraan itu sendiri. Jalur pejalan kaki yang ada di kawasan Blok $\mathrm{M}$ juga belum ramah bagi penyandang disabilitas terkait dengan kurangnya ramp dan tidak tersedianya guiding block di jalur pejalan kaki terutama yang berada di kawasan Blok M Square dan Terminal Bus Blok M. Kondisi jalur pejalan kaki juga masih banyak rusak/berlubang. Kemudian tidak adanya fasilitas pendukung seperti tempat sampah, tempat duduk di jalur pejalan kaki kawasan Blok M. Hal ini tentunya sangat disayangkan disebabkan melihat potensi yang terjadi apabila terdapat kenaikan KLB baik yang disesuaikan oleh RDTR 2030 maupun PRK 2020. Apabila terjadi kenaikan KLB maka akan terjadi kenaikan jumlah penumpang dimana jalur pejalan kaki menjadi potensial untuk digunakan oleh penumpang.

Terkait aktivitas pendukung yang paling mendominasi dari kawasan Blok $\mathrm{M}$ ini adalah pusat perbelanjaan, dan yang kedua merupakan pertokoan. Berdasarkan teori yang ada untuk aktivitas pendukung yang ada di kawasan Blok $\mathrm{M}$ sudah mencakup semua hal yang dibutuhkan. Sub blok yang ada juga berpotensial untuk dilewati baik oleh penumpang maupun wisatawan bila nantinya akan ada peningkatan KLB di kawasan Blok M. Hal ini akan membuat kawasan Blok M menjadi lebih berkembang, tingkat produktivitas menjadi tinggi dan dapat menarik masyarakat untuk datang ke kawasan ini.

\section{Saran}

Berikut adalah saran yang dapat diberikan berdasarkan hasil studi yang telah dilakukan :

1. Dalam meningkatkan mobilitas penumpang yang ada di kawasan Blok M, PT MRT Jakarta yang bertugas dalam mengelola kawasan TOD Blok $M$ ini, perlu memperhatikan terkait dengan jalur perpindahan moda transportasi antara stasiun dengan terminal. PT MRT Jakarta perlu mempercepat rencana pembangunan jembatan penyebrangan yang menghubungkan antara Stasiun MRT dengan Terminal Bus.

2. PT MRT Jakarta perlu melakukan kerja sama dengan pihak developer dari kawasan Blok M Square untuk melakukan perbaikan jalur pejalan kaki yang sudah rusak serta membuat jalur pejalan kaki yang ada menjadi ramah bagi penyandang disabilitas seperti dengan adanya penambahan ramp dan guiding block. Kemudian perlu adanya penambahan fasilitas pendukung seperti tempat duduk, tempat sampah, dan peneduh di jalur pejalan kaki, demi meningkatkan kenyamanan bagi pejalan kaki.

3. Selain bekerja sama dalam melakukan perbaikan kondisi jalur pejalan kaki, perlu juga dilakukan penertiban yang tegas bagi kendaraan bermotor yang menggunakan jalur pejalan kaki sebagai tempat parkir dan jalan, sehingga keamanan dan kenyamanan pejalan kaki terjamin.

4. Terkait dengan aktivitas pendukung yang ada di kawasan Blok $M$ ini, perlu mempercepat tahap pengembangan terutama di kawasan Blok M Square dan memperhatikan jalur pejalan kaki yang terkoneksi antara stasiun/terminal dengan aktivitas pendukung. Sehingga dengan mempercepat 
tahap pengembangan kawasan ini diharapkan dapat menjadi daya tarik masyarakat untuk berkunjung, berjalan, dan menggunakan moda transportasi di kawasan ini. Dalam melakukan tahap pengembangan kawasan Blok M, PT MRT Jakarta dapat melakukan kerja sama dengan developer yang ada di kawasan Blok $\mathrm{M}$

\section{REFERENSI}

Aono, S. (2019). Identifying Best Practices for Mobility Hubs. Vancouver: UBC Sustainability Scholar. Kaliongga, F. G., Kumurur, V. A., \& Sembel, A. (2014). Kajian Aspek Kenyamanan Jalur Pedestrian. Manado: SABUA.

Leather, J., Fabian, H., Gota, S., \& Meija, A. (2011). Walkability and Pedestrian Facilities in Asian Cities State and Issues. Metro Manila: Asian Development Bank.

Metrolinx. (2008, December 7). Backgrounder: Mobility Hubs. Diambil kembali dari Metrolinx: http://www.metrolinx.com/en/

New Jersey Department of Transportation. (2016). Pedestrian Compatible Planning and Design Guidelines. New Jersey: New Jersey Department of Transportation.

OECD. (2002). Guidelines towards Environmentally Sustainable Transport; Organization for Economic Co-operation and Development. Paris: OECD Publication Services.

Suryani, L. (2006). Pola Pergerakan Pejalan Kaki di Pusat Kota Medan. Medan: Sekolah Pascasarjana Universitas Sumatera Utara (USU).

Tanan, N., Wibowo, S. S., \& Tinumbia, N. (2017). Pengukuran Walkability Index Pada Ruas Jalan di Kawasan Perkotaan. Jalan - Jembatan.

Voorhees, A. M. (2019). TNJ Guidebook for Transit Hub Planning. New Jersey: US Department of Transportation. 